DOI https://doi.org/10.30525/978-9934-26-046-9-40

\title{
ВИКОРИСТАННЯ РИСОВОГО БОРОШНА В ТЕХНОЛОГІЇ БІСКВІТНОГО ПЕЧИВА
}

\author{
Шелудько В. М. \\ кандидат технічних наук, доцент, \\ доцент кафедри технологій харчових виробнищтв \\ і ресторанного господарства \\ ВНЗ Укоопспілки «Полтавський університет економіки і торгівлі»

\begin{abstract}
Фaxypi M.
студент денної форми навчання

Навчально-науковий інститут харчових технологій, готельно-ресторанного та туристичного бізнесу

ВНЗ Укоопспілки «Полтавський університет економіки і торгівлі» м. Полтава, Украӥна
\end{abstract}

В сучасному світі з розвитком технологій людина отримує енергії (калорій) більше, ніж витрачає, що призводить до виникнення надлишкової ваги, захворювань серця. Сьогоднішній споживач більшою мірою надає перевагу здоровому харчуванню, що сприяє зростанню темпів розвитку асортименту борошняних кондитерських виробів. У кожного народу існують свої історично сформовані особливості харчування. Сьогодні процес запозичення національних виробів йде дуже швидко. Борошняні вироби містять значну кількість цукру, жиру і майже не містять вітамінів і макро-, мікроелементів. В Україні великою популярністю наразі серед молоді користуються капкейки, маффіни, м'які вафлі, біскотті та ін. [1, с. 30; 2, с. 47].

Бісквітне печиво займає вагоме місце у виробництві борошняних кондитерських виробів і користується великим попитом у населення. Розробка технологій борошняних кондитерських виробів із використанням рослинної сировини підвищеної харчової цінності - важливе питання, яким займались різні учені у свій час. У своїх експериментах вчені у значній мірі застосовували фруктову, овочеву сировину і злаки.

Рис вважається однією з найстаріших окультурених злакових рослин в світі. Фрагменти його переробки були знайдені в Китаї в шарах, яким більше 11 тисяч років. Батьківщиною культури $є$ південний схід 
Євразійського континенту. В даний час існує близько 2500 сортів, в основному культивується в тропіках і субтропіках Азії, Африки, Америки та Австралії. Рис - однорічна рослина родини злакових. Цінна зернова культура - основний харчовий продукт для більшої частини населення нашої планети і друга за значенням зернова культура після пшениці [3 с. 129; 4 с. 4].

Актуальним $€$ питання розширення асортименту борошняних кондитерських виробів підвищеної харчової цінності. Такими виробами $\epsilon$ бісквітне печиво «Мадлен» $\mathrm{i}$ «Савоярді».

«Мадлен» (фр. Madeleine) - французське бісквітне печиво невеликого розміру, зазвичай виготовляється у формі морських гребінців. Ця випічка користується незмінним успіхом у Франції і Свропі в цілому. Своєю всесвітньою популярністю печиво «Мадлен» зобов'язане роману Марселя Пруста «У пошуках втраченого часу».

Основною сировиною для виробництва бісквітного печива «Мадлен» є борошно, вершкове масло, цукор і яйця. Для отримання печива спочатку розм'якшують вершкове масло і збивають протягом 7-10 хв., додають половину кількості цукру-піску і збивають ще 5-7 хв., потім додають сік и цедру лимона. Яйця і жовтки збивають з рештою цукрупіску протягом 10 хв. до утворення стійкої піни. До збитої яєчної маси додають суміш просіяного пшеничного борошна і розпушувача, потім додають збите вершкове масло. Все ретельно перемішують. Готове тісто за допомогою кондитерського мішка викладають у спеціально підготовлені форми для печива «Мадлен» у вигляді морської мушлі. Випікають при температурі $200-220^{\circ} \mathrm{C}$ протягом 10 хв. Готове печиво охолоджують.

Технологічна схема приготування «Мадлен» складається 3 послідовності наступних операцій: підготовка сировини до виробництва, дозування, заміс тіста, формування, випічка, зберігання [5, с. 129].

Печиво «Савоярді» було винайдено ще в XV столітті в Італії, при дворі герцогів Савойський. Кухар винайшов рецепт з приводу приїзду короля Франції в графство Савойя. Печиво має і іншу назву - «Дамські пальчики». Виріб має м'яку і ніжну консистенцію, відмінно вбирає сиропи і джеми, завдяки чому використовується як основа багатьох десертів. Для приготування бісквітного печива «Савоярді»: спочатку відділяють білки від жовтків. Жовтки збивають з цукром протягом 5-7 хв., додають просіяне пшеничне борошно. Окремо збивають білки до гострих піків і поступово додають їх до яєчно-борошняної суміші, замішують тісто. За допомогою кондитерського мішка викладають тісто у заздалегідь підготовлені форми для печива. Випікають 
12-14 хв. при температурі $180-190{ }^{\circ} \mathrm{C}$. Готове печиво охолоджують і звільняють з форми [6 с.3].

Досліджень із використанням рисового борошна для збагачення печива «Мадлен» і «Савоярді» біологічно активними речовинами та підвищення його харчової цінності не проводилося. Тому існує необхідність таких досліджень.

Метою роботи було удосконалення технологій і розширення асортименту бісквітного печива «Мадлен» і «Савоярді» $з$ використанням рослинної сировини підвищеної харчової цінності - рисового борошна. Були складені модельні системи - зразки печива із вмістом рисового борошна від сухих речовин пшеничного борошна у кількості від $10 \%$ до 30 \%. Проведені експериментальні дослідження по визначенню фізико-хімічних, структурно-механічних, органолептичних показників якості виробів. Встановлено, що розроблені зразки печива «Мадлен» і «Савоярді» мали високі органолептичні показники якості, набули оригінального смаку та запаху за рахунок внесення добавки. Найкращими показниками якості відрізнялись зразки бісквітного печива «Мадлен» $\mathrm{i}$ «Савоярді», що містять 20 \% рисового борошна.

\section{Література:}

1. Шелудько В.М. Нові види борошняних кондитерських виробів в Україні. Хранение и переработка зерна. 2011. № 6. С. 30-32.

2. Шелудько В.М., Ряшко Г.М. Вивчення можливості використання овочевого пюре в технології маффінів. Хранение и переработка зерна. 2016. № 5. С. 47-51.

3. Карпюк Г.С., Шелудько В.М. Удосконалення технології капкейків за рахунок додавання рослинної сировини. 3б. наук. статей магістрів ф-ту ХТГРТБ ПУЕТ за результатами 2016-2017 н.p. 2016. С. 129-132.

4. Склад інгредієнтів для капкейка: пат. 116636 Україна, МПК A23L7/00. № U201613326; заявл. 26.12.2016; опубл. 25.05.2017, Бюл. № 10.4 c.

5. Корягін А.А., Шелудько В.Н. Улучшение качества бисквитного печенья «Мадлен» с использованием растительного сырья. Инновационный потенцииал молодежи в современном мире: тезисы доклада XXXVII Международной науч.-практ. конф. (Гомель, 10 -12 мая 2017 г.). Гомель, 2017. С. 129.

6. Спосіб приготування бісквітного печива «Савоярді»: пат. 146215 Україна; МПК A21D 2/00. №U202005805; заявл. 10.09.2020; публ. 27.01.2021, Бюл. № 4.3 c. 